\title{
Rola NATO w regulacji światowego porządku. Wyzwania i zagrożenia dla bezpieczeństwa w XXI wieku
}

Abstrakt: Wojny w Afganistanie czy Iraku to etapy większego zjawiska, którym jest wojna z terroryzmem. Wymaga ona cierpliwości, porozumienia i dialogu międzycywilizacyjnego, lecz nie wąsko pojętego w ujęciu Huntingtona, tylko szeroko rozumianego dialogu cywilizacji ludzkiej.

Każda wojna jest do wygrania, jeżeli priorytetem w niej nie jest dążenie do hegemonii w świecie, ale do bezpieczeństwa własnych obywateli. Dlatego by możliwe było stworzenie nowego systemu bezpieczeństwa światowego, który poprzez sieć systemów regionalnych utworzyłby pewnego rodzaju zaporę chroniącą przed terrorystami, równocześnie ze stabilizacją należy prowadzić dialog ze społecznością muzułmańską i nie tylko. Stworzenie takiego systemu musi być priorytetem dla polityków i państw, które reprezentują.

Polityk jak każdy człowiek ma prawo do błędnej decyzji. Jednakże przy jej podejmowaniu musi liczyć się z konsekwencjami. Tym większymi, im ranga decyzji jest wyższa, albowiem decyzja o wojnie jest jedną z najbardziej brzemiennych w skutki.

Słowa kluczowe: polityka, konflikt, bezpieczeństwo międzynarodowe, NATO, współpraca militarna

NATO's role in regulating the world order. Challenges and threats to security in the 21st century

Abstract: The wars in Afghanistan or in Iraq are just stages of a wider phenomenon of war against terrorism. War requires patience, understanding, dialogue within a civilization, but not the one narrowly understood as Huntington sees it, but general human civilization. Each war can be won if its priority is not to try to conquer the world but to win security for the inhabitants of a state. Therefore, stabilization should be accompanied by dialogue with the Muslim community, but not only with that community if a new system of world security is to be created. A network of regional systems that would form a kind of anti-terrorist dam should be created. The appropriate formation of such a system must be a priority for politicians and the states they represent. Like any other man, 
a politician can sometimes make a wrong decision. However, he or she must be aware of its consequences when taking it. The more serious the consequences, the higher the rank of the decision. The decision to wage war is, however, the most burdened with consequences of all decisions.

Keywords: politics, conflict, international security, NATO, military cooperation

\section{Wstęp}

Każdy sojusz, czy to wojskowy, czy też li tylko polityczny, jest wart tyle, ile są gotowe zrealizować strony zawierające porozumienie. Okres, w którym powstał Pakt Północnoatlantycki, był trudny tak dla państw europejskich, jak teź świata doświadczonego efektami działań zbrojnymi okresu drugiej wojny światowej ${ }^{1}$.

Błędy, które popełniły zwycięskie mocarstwa alianckie, automatycznie przekładały się i rzutowały na kształt powojennego świata. Dwubiegunowy podział świata na obóz demokratycznego Zachodu i komunistycznego Wschodu był wyznacznikiem sposobu postrzegania rzeczywistości poprzez ideologiczną konfrontację. A przynajmniej tak starano się przedstawiać sytuację w przestrzeni publicznej. W rzeczywistości, jeżeli oceniać tę rywalizację z perspektywy czasowej, pomijając całą otoczkę marketingu politycznego nakierowaną na maksymalne zwiększenie liczby zwolenników, widoczny staje się element będący stałym punktem każdej rywalizacji w historii ludzkości.

Tym elementem jest permanentna walka o władzę polityczną i duchową nad społeczeństwami. Duchowa forma walki dotyczy sfery, którą można scharakteryzować jako serca i umysły. Jest ona o tyle istotna, o ile władcy i przywódcy polityczni zdają sobie sprawę z wagi pomnażania liczby zwolenników. Nie wystarczy bowiem zdobyć władzę, istotne jest to, aby ją utrzymać i rozszerzyć. Paradoksalnie ta zasada nie dotyczy jednego wybranego ustroju, ale wszystkich rodzajów i sposobów sprawowania władzy. Okres rywalizacji Wschodu z Zachodem nie tyle wydaje się wpisywać, co istotnie spełnia kryteria walki o władzę we wszystkich elementach niezbędnych do wygrania przez jeden z obozów takiej rywalizacji. Osiągnięcie takiego sukcesu leżało w jedności, a tę można było osiągnąć za pomocą zinstytucjonalizowanych form współpracy, takich właśnie jak wspomniany wcześniej Pakt Północnoatlantycki².

Stany Zjednoczone Ameryki, które ze względu na swoją militarną i ekonomiczną siłę w naturalny sposób stały się liderem grupy państw demokratycznych, w dość dużym stopniu starały się przeforsować własną wizję świata demokratycznego. Zwłaszcza w rejonach określanych jako Trzeci Świat, do którego w większości zaliczały się podmioty państwowe, które wyszły z okresu zależności od w większości przypadków - mocarstw zachodnich i podlegały tzw. procesowi

${ }^{1}$ R. Zięba, Wspólna polityka zagraniczna i bezpieczeństwa Unii Europejskiej, Wrocław 2007, s. $15-18$.

2 M. McCauley, Rosja, Ameryka i Zimna Wojna, przeł. R.A. Galos, Wrocław 2001, s. 12-19. 
dekolonizacji. Innymi słowy, dawne państwa kolonialne walczyły o ustanowienie systemu demokratycznego w swoich dawnych posiadłościach, tym samym rywalizując z autorytarnym Związkiem Socjalistycznych Republik Radzieckich, który pragnął zetrzeć wszelkie ślady obecności swoich zachodnich rywali i zastąpić ich zwolenników ugodowymi wobec Moskwy politykami. Kartą atutową w przekonaniu radzieckich przywódców miał być wrogi Zachodowi system polityczny ${ }^{3}$.

Warto, a nawet trzeba zaznaczyć w tym miejscu, że dla osiągnięcia ostatecznego sukcesu obydwie strony nie przebierały w środkach. Jednak czy głównym celem było osiągnięcie takiego sukcesu, jakim był upadek ZSRR jako formy państwowej, jest - jak się wydaje - kwestią dyskusyjną. Zwłaszcza gdy ocenia się i analizuje okres, który wraz z upadkiem ZSRR nastąpił po zimnowojennej rywalizacji, a w którym mnożyły się różne warianty mające na celu ugruntowanie światowego przywództwa Ameryki i to bez względu na to, czy Amerykanie byli, czy też nie byli w stanie unieść odpowiedzialności związanej z takim liderowaniem.

Upadek Wschodu stawiał również pod znakiem zapytania sensowność, a także celowość funkcjonowania NATO jako paktu o charakterze odstraszającym. Wbrew oczekiwaniom rozwiązanie prokomunistycznego Układu Warszawskiego nie tyle nie zakończyło funkcjonowania jego zachodniego adwersarza, ile umocniło go po zgłoszeniu akcesu do NATO przez dawnych członków Układu Warszawskiego, co z kolei spotkało się z ostrą, a tym samym również negatywną reakcją powstałej na gruzach ZSRR jego spadkobierczyni, jaką bez wątpienia jest Federacja Rosyjska. Z tej przyczyny proces dochodzenia do członkostwa w Pakcie Północnoatlantyckim był dla państw Europy Środkowej i Wschodniej długotrwałym etapem trwającym do 1999 r. Jednak do tego wydarzenia zmiany, które zachodziły w przestrzeni geopolitycznej, ukształtowały nowy sposób postrzegania relacji w obszarze współpracy i rywalizacji, oraz USA jako czynnika stabilizującego na kontynencie europejskim. Ta rola uwidoczniła się zwłaszcza po wojnie, jaka miała miejsce w trakcie procesu rozpadu Jugosławii, gdy państwa europejskie samodzielnie okazały się zbyt bezradne, by położyć kres przemocy.

To umocniło amerykańskie elity polityczne w przekonaniu, że Europa jest zbyt słaba, aby liczyć się jako równorzędny partner. Ten sposób postrzegania roli sojuszu doprowadził do tzw. podziału na starą i nową Europę w świetle planowanej i przeprowadzonej w 2003 r. operacji irackiej. Warto w tym miejscu pochylić się nad kwestią stosunków na linii USA-Irak, bo to właśnie ten zatarg stał się poniekąd zarzewiem kolejnych źródeł konfliktogennych na Bliskim Wschodzie i umożliwił swobodny przepływ ludzi zasilających kolejne powstające organizacje o charakterze terrorystycznym ${ }^{4}$.

3 Tę tematykę szczegółowo poruszono w pracy bazującej na dokumentach radzieckich służb wywiadowczych, które opracował płk Oleg Gordijewski. Zob. Ch. Andrew, O. Gordijewski, KGB, Warszawa 1999, s. 324-408.

${ }^{4}$ Według S. Tannera zasadne byłoby położenie nacisku na umiejętność prowadzenia polityki wobec tak odmiennych kulturowo państw jak Irak. I nie chodzi w tym wypadku o kwestie wiary, ale 
I.

Istotne w tym miejscu jest to, że łatwo krytykować czyjś system rządów w momencie gdy oferta zastępcza jest nie tyle praktyczna, ile przede wszystkim realna, czyli niezakłócająca dotychczasowych stosunków międzyludzkich.

Amerykanie i ich sojusznicy, w tym Polacy, obalili reżim, który w okresie trwania zimnej wojny służył interesom Zachodu, a po jej zakończeniu i agresji Iraku na Kuwejt stał się kłopotliwym problemem. Na temat przyczyn i konsekwencji operacji w Iraku napisano wiele analiz, z których większość sprowadza się do wniosku, że bez uprzedniego rozeznania w konstrukcji państwa i kultury jego obywateli każda operacja mająca zamienić jeden system mocno osadzony w tradycji na system obcy wywodzący się z tradycji mało zrozumiałych w danym rejonie świata zazwyczaj kończy się mniej lub bardziej spektakularną klęską. Ta z kolei prowadzi do prawomocności decyzji Amerykanów, którzy mimo statusu supermocarstwa nie są samotną wyspą, lecz państwem powiązanym siecią porozumień i układów międzynarodowych z państwami będącymi członkami NATO, którego — jak zauważono - USA jest liderem ${ }^{5}$.

Pakt Północnoatlantycki ma charakter sojuszu obronnego, a nie ofensywnego, co bezpośrednio przekłada się na to, że nie stworzono go dla podboju i chwały, jak to miało miejsce w przypadku sojuszów zawieranych w historii nie tyle Zachodu, ile całej ludzkości. W dawnych sojuszach sprzymierzeńcy z przyjaciół szybko stawali się wrogami, co jasno pokazuje historia powstania imperium Persji czy też wojen na Peloponezie, ale miała miejsce również w przypadku starożytnych Chin czy otomańskiej Turcji. W dziedzinie zawierania układów sojuszniczych i łamania traktatów nie ma, jak się wydaje, kraju, który byłby nowicjuszem. W polityce zawsze bowiem liczyła się racja stanu i chęć przetrwania. A bez tego drugiego elementu żadna próba dominacji w świecie nie miałaby miejsca.

W odróżnieniu od tych przykładów celem NATO była wzajemna, oparta na zaufaniu współpraca, co tworzyło nową jakość w przestrzeni geopolitycznej ${ }^{6}$. To zaufanie nadwyrężyły działania USA. Jednakże pomyłką wydaje się mnożenie analiz skupiających się na popełnionych na Bliskim Wschodzie błędach, a to dlatego że jeżeli od początku planowania zabrakło refleksji nad różnicami w podejściu do

podejście do uprawiania skutecznej polityki i zarządzania państwem. Ta kwestia została omówiona m.in. w pracy S. Tanner, Wojny Bushów. Ojciec i syn jako zwierzchnicy sił zbrojnych, przeł. J. Lang, Wrocław 2007, s. 199-270.

5 Ale nie zawsze o tym chcą pamiętać. A to z kolei musi skutkować konfliktami wewnątrz Sojuszu. Interesujący pogląd na temat istoty nieporozumień pomiędzy USA a jego europejskimi sojusznikami prezentuje E. Todd, Schyłek imperium. Rozważania o rozkładzie systemu amerykańskiego, przeł. A. Szeptycki, K. Mączyńska, Warszawa 2003, s. 191-231.

6 Por. A. Dybczyński, Organizacja Traktatu Pólnocnoatlantyckiego, [w:] Organizacje w stosunkach międzynarodowych. Istota - mechanizmy działania - zasięg, red. T. Łoś-Nowak, Wrocław 2009, s. 273-290. 
podstawowych wartości, jaką jest np. wolność, to pozostałe działania, które można postrzegać jako błędne, są jedynie konsekwencjami wcześniejszych decyzji.

$\mathrm{W}$ polityce, zwłaszcza tej prowadzonej na scenie międzynarodowej, każde odstępstwo od przyjętych reguł może być wyolbrzymione i potraktowane jako skandaliczne i niedopuszczalne. Próby zasłaniania się niewiedzą lub małym doświadczeniem paradoksalnie mogą taką sytuację pogłębić 7 .

Podobnie przedstawia się kwestia interwencji zbrojnej państwa będącego członkiem danej organizacji, z pominięciem głosowania nad racjonalizmem podjętej subiektywnie decyzji o interwencji zbrojnej. Co istotniejsze, operacja iracka dowiodła, jak ważna jest sprawdzona informacja i jakie znaczenie ma wiedza oparta na niepotwierdzonych lub przestarzałych danych.

Ważnym aspektem wojen na Bliskim Wschodzie i związanego z nimi rozwoju terroryzmu międzynarodowego jest to, że po analizach opinii takich badaczy jak Samuel P. Huntington, Chalmers Johnson, Francis Fukuyama ma się wrażenie próby zbudowania nowego porządku bipolarnego, gdzie z jednej strony ma się do czynienia z nowoczesnym, postępowym Zachodem, a z drugiej ze skrajnie fundamentalnymi organizacjami religijnymi, sponsorowanymi przez autorytarne reżimy, których jedynym narzędziem prowadzenia polityki jest sianie terroru przez zamachy, porwania i eksterminowanie wszystkich uznanych za oponentów ${ }^{8}$.

Takie skrajne, a tym samym uproszczone zestawienie nie ma wiele wspólnego $\mathrm{z}$ analizą rzeczywistości, co więcej sprawia wrażenie próby stworzenia narracji mającej za zadanie racjonalnie wytłumaczyć sposób podejmowanych ad hoc przez polityków decyzji. A z takimi decyzjami mamy, jak można przypuszczać, do czynienia po spektakularnych i tym samym medialnych zamachach terrorystycznych z 11 września 2001 r. Stał za nimi saudyjski miliarder Osama bin Laden, który przez ten akt politycznego terroru rozreklamował założoną przez siebie organizację znaną pod nazwą Al-Kaida. Nie była to organizacja w zachodnim rozumieniu, ale raczej baza (stąd nazwa) grupująca wiele ekstremistycznych organizacji, które po zakończeniu zimnej wojny potrzebowały nowego zdefiniowania i celu, czyli sensu swojego istnienia. Osama bin Laden ten cel im dał, a Zachód przez wspólną, solidarnościową ze Stanami Zjednoczonymi deklarację o uruchomieniu piątego punktu Paktu Północnoatlantyckiego i wypowiedzeniu wojny terrorystom uczynił ten cel medialnie atrakcyjnym. Nie oznacza to, że poparcie USA było pozbawione sensu, ponieważ pokazało, że w kryzysowych sytuacjach USA może liczyć na swoich sojuszników. Niestety nieskoordynowanie przy wyborze celów i dobieranie sobie przez Amerykanów sojuszników pod kątem bieżąco realizowanej polityki sprawiło, że terroryzm międzynarodowy zamiast słabnąć wzrasta i osiąga poziom, którego

\footnotetext{
7 Na co wskazuje w swojej analizie M. Dobry. Por. idem, Socjologia kryzysów politycznych, Warszawa 1995, passim.

8 Por. R.A. Kosta, Oblicza zjawiska polityki w życiu publicznym w XXI wieku, Częstochowa 2016, s. 41-97.
} 
konsekwencje są odczuwalne w postaci rozlewania się konfliktów na coraz większą liczbę państw i wzrostu liczby uchodźców z tych państw9 9

Jednak to tylko jeden z problemów. Innym jest to, że koncentracja na jednym polu może osłabić zdolność adekwatnej reakcji w sytuacji, gdy zamiast organizacji przeciwnikiem bądź rywalem staje się państwo lub grupa państw. Jakkolwiek między określeniem „przeciwnik”, którego utożsamia się z wrogiem, a „rywal” jest subtelna różnica polegająca na prowadzeniu tzw. słabej i mocnej polityki, to zasada działania jest podobna, ponieważ spór dotyczy zakresu interesów prowadzonych przez państwa i zysków, jakie te interesy przynoszą konkretnym państwom. Wojna osłabia zasoby zarówno ludzkie, jak i materialne i jest korzystna dla rywala, który nie jest w nią na tak dużą skalę zaangażowany, tylko liczy na korzyści po jej zakończeniu.

Do takich państw spoza obozu natowskiego możemy zaliczyć Federację Rosyjską i Chińską Republikę Ludową oraz Islamską Republikę Iranu. Choć niektóre państwa, w tym USA, widzą w tym trzecim podmiocie państwowym sponsora terroryzmu, to jednakże sytuacja jest, jak się wydaje, bardziej złożona i bezpośrednio wpływa na kształt bliskowschodniej polityki NATO, zwłaszcza gdy zauważy się, jak ważkie i istotne interesy oprócz USA mają w tym regionie Turcja, a także Republika Francji i Zjednoczone Królestwo Wielkiej Brytanii i Irlandii Północnej Turcja ze względu na położenie, a pozostałe państwa ze względu na swoją długofalową i historyczną politykę. Nie można o tym zapominać. Zwłaszcza w przypadku państw tworzących politykę opartą na wypracowanych przez stulecia wzorcach, od których, jak w przypadku Wielkiej Brytanii, odstępstwo jest wyjątkiem, a w praktyce jest tak rzadkim zjawiskiem, że właściwie niemożliwym do zaakceptowania przez siły polityczne, bez względu na barwę polityczną i deklarowane poglądy ${ }^{10}$.

\section{II.}

Podstawą każdego sojuszu wojskowo-politycznego jest spójność w podejmowaniu działań i realizowaniu zadań, których konsekwencje mogą odbić się na jakości sojuszu, tym samym niszcząc zaufanie, które jest niezbędne, by dane przymierze mogło mieć jakąkolwiek przyszłość.

W prowadzonych badaniach przyzwyczajono się postrzegać NATO jako trwały element ładu światowego. Co więcej, całkowicie pomija się to, że członków Paktu Północnoatlantyckiego łączą wyrażane wartości i dążenia. Jednym z nich i, jak się wydaje, podstawowym jest walka $\mathrm{z}$ międzynarodowym terroryzmem. W tym jednym aspekcie członkowie sojuszu są zgodni, przy czym widać, że interpretacja, czym jest terroryzm i kto tym terrorystą jest, nie jest już tak oczywista. Powraca

9 Por. R.A. Kosta, Idea bezpieczeństwa i pokoju w polityce mocarstw anglosaskich, Częstochowa 2016, s. 157-208.

10 Ibidem, s. 249-253. 
tu problem stosunku do Iranu, który od rewolucji z 1979 r. przez kolejne rządy sprawujące władzę w USA jest traktowany jeżeli nie jako źródło terroryzmu na Bliskim Wschodzie, to przynajmniej jako sponsor radykalnych organizacji, takich jak libański Hezbollah. Pomija się jednak, że ta organizacja jest jedyną wspieraną przez Iran i jej rola nie jest obecnie tak oczywista, jak była w latach 80 . ubiegłego wieku, gdy toczyła się zimna wojna ${ }^{11}$.

Tym, co różni opinie polityczne od naukowych analiz, jest to, że polityk może, choć nie zawsze powinien, traktować wszystko na zasadzie przeciwieństwa białe-czarne. Naukowiec nie może jednak sobie na to pozwolić i jego sceptycyzm i chłodne podejście musi przeważać nad politycznymi sympatiami i antypatiami. Problem Libanu, dawnej Szwajcarii Wschodu, jest zbyt złożony, by omówić go w niniejszej analizie. Warto tylko podkreślić, że jest to państwo, którego problemy dotyczą zarówno jego mieszkańców, jak i państw Zachodu i Układu Warszawskiego, które urządziły sobie na Bliskim Wschodzie poligon walki ideologicznej. Współcześnie walkę demokracji z komunizmem zastępuje walka liberalnej demokracji z fundamentalizmem religijnym. I tego problemu NATO nie rozwiąże środkami militarnymi, ale wyłącznie politycznymi, na co wskazują doświadczenia wojen: afgańskiej, irackiej, a w drugiej dekadzie XXI wieku syryjskiej i jemeńskiej. Przy czym warto zaznaczyć, że o tej ostatniej, w którą są zaangażowani zarówno Irańczycy, jak i Saudyjczycy, nie mówi się tyle co o zasobnym w ropę Iraku. I tu pojawia się problem, czy państwom NATO chodzi o stabilizację, czy raczej o dochody ze złóż ropy naftowej i jej regularne dostawy, tak niezbędne w rozwoju gospodarek państw wysoko rozwiniętych ${ }^{12}$.

Tego rodzaju uwaga wydaje się zasadna, o ile pamięta się słowa Raymonda Arona, który twierdził, że państwo lub grupa państw angażując się lub rozpoczynając daną wojnę, są zobowiązane do posiadania konkretnych planów podboju, bez nich bowiem każda operacja, jak wiele konfliktów znanych z niedalekiej przeszłości, musi skutkować mniej lub bardziej spektakularną porażką. I paradoksalnie dlatego zasoby naturalne Bliskiego Wschodu byłyby wytłumaczeniem pewnego rodzaju nielogiczności w podejściu do spraw tego regionu. Regionu, który jest kluczem do budowy skutecznego systemu bezpieczeństwa, w którym to NATO pozostawałoby głównym rozgrywającym ${ }^{13}$.

Problem w tym, że od czasu wspomnianego sztucznego podziału na starą i nową Europę państwom członkowskim niebywale trudno jest wypracować wspólną politykę co do kierunku rozwoju, która odpowiadałaby i tym samym spełniałaby oczekiwania wszystkich członków sojuszu. Zwłaszcza w kwestii finan-

11 Szerzej ten temat został poruszony w pracy H. Jaber, Hezbollah. Walka i zemsta, przeł. J. Kozłowski, Warszawa 1999, s. 19-63 n.

12 A takie pytania zadają sobie również badacze spoza zachodniego kręgu kulturowego. Por. S. Amin, Zmurszały kapitalizm, przeł. R. Wojna, Z.M. Kowalewski, Warszawa 2004, s. 99-149.

13 R. Aron, Wojna i pokój między narodami (teoria), przeł. A. Mielczarek, Warszawa 1995, s. $37-38 \mathrm{n}$. 
sowania organizacji, modernizacji sprzętu, jak też w ustaleniu klucza zagrożeń, który będzie istotną kwestią w miarę wzrostu zagrożenia ze strony kolejnych organizacji terrorystycznych. Państwa te będą powstawać, jak można przypuszczać, wraz z kolejnymi kryzysami na Bliskim Wschodzie. Region ten powoli staje się najbardziej zapalnym rejonem świata i największą porażką wizerunkową Paktu Północnoatlantyckiego, zwłaszcza po tym jak zainteresowanie tym regionem zaczęły wyrażać państwa, które uznano za mało znaczące w rywalizacji po zakończeniu zimnej wojny, a są one kluczowymi graczami na światowej szachownicy ${ }^{14}$.

Jeżeli organizacja zrzeszająca niepodległe, suwerenne państwa aspiruje do bycia światowym żandarmem pilnującym pokoju i stabilności, a nie chce być li tylko elitarnym klubem, to musi nie tyle posiadać strategie rozwiązywania problemów, ile przede wszystkim je realizować. Natomiast jeżeli Pakt Północnoatlantycki ma w swoich założeniach ochronę własnych członków, powinien uwzględnić, że realizacja interesów poszczególnych członków może stać w sprzeczności z celami strategicznymi sojuszu postrzeganego z perspektywy całości organizacji.

Perspektywa rozwoju Paktu Północnoatlantyckiego pod kątem radzenia sobie z zagrożeniami i wyzwaniami, jakie niesie dynamika wzrostu kryzysów na świecie w XXI w., musi być badana również z uwzględnieniem tego, jak sojusz jest postrzegany, a także tego, jakim chcieliby go widzieć uczestnicy Paktu Północnoatlantyckiego.

\section{III.}

Zanim jednak przejdziemy do kwestii przyszłości, warto przypomnieć, że o zwycięstwie państwa czy też koalicji państw przeważnie nie decyduje liczba wojsk i jakość sprzętu, ale czynnik ludzki, szerzej: wszystko, co wiąże się z morale, czyli kluczem do zwycięstwa są bezpieczeństwo wewnętrzne, silna gospodarka i zamożne społeczeństwo, które zgodzi się na każdą operację swoich sił szybkiego reagowania, w ramach demokratycznego państwa prawa, które zachowa dotychczasowe status quo. Tym celom miała służyć tzw. wojna $\mathrm{z}$ terroryzmem i w przypadku USA, na którego terytorium nie było dużych zamachów podobnych do zniszczenia WTC, zdała ona egzamin.

Natomiast zamachy w Madrycie, Londynie, na Bali i wiele innych pomniejszych aktów terrorystycznych ukazują specyfikę nowej formy walki, która coraz mniej przypomina wojnę asymetryczną, chyba że ktoś uzna Państwo Islamskie za coś więcej niż organizację pragnącą zdominować świat. Skala, zakres i uczestnicy-ochotnicy oddziałów skrajnych fundamentalistów religijnych jednoznacznie wskazują na hybrydową formę konfliktu. W wojnach ideologicznych, gdzie liberalna wizja świata zderza się z autorytarną i patriarchalną formą władzy, w której porządek świata jest indywidualną wizją szefa danej organizacji, o zwycięstwo jest niezwykle trudno. Zwłaszcza po falstarcie, jaki miał miejsce w Iraku, i nowych po-

\footnotetext{
14 Por. S. Amin, op. cit., passim.
} 
ligonach, które mogły zaistnieć po rewolucji w Północnej Afryce, a zwłaszcza po upadku despotycznego i autorytarnego reżimu w Libii, czyli państwie, które w realny sposób uprawiało terror państwowy, jak też stało za niektórymi zamachami terrorystycznymi z okresu zimnej wojny ${ }^{15}$.

Warto również nadmienić, że inaczej walczy się z przeciwnikiem, którego potencjał i możliwości są znane, a zupełnie inaczej kiedy o sile i zasobach można domniemywać i szacować na podstawie wirtualnych danych, zwłaszcza gdy działa się na terenie uznanym za obcy kulturowo. Takie schematyczne postrzeganie innych kultur sprawia bowiem, że poszukuje się odmienności, zamiast skupić się na elementach wspólnych. Każdy naród ma prawo do wyrażania swoich poglądów, ale wszystkie ludzkie społeczności łączy potrzeba bezpieczeństwa i dążenie do obrony. Zwłaszcza w przypadku gdy ktoś stawia ultimatum, jak to miało miejsce na Bliskim Wschodzie, Azji Południowo-Wschodniej i innych rejonach świata ${ }^{16}$.

Polska, będąc do 1989 r. w obozie wschodnim, nie musiała przed przystąpieniem do NATO liczyć się z konsekwencjami, jakie musiał w sferze wizerunkowej ponieść Zachód, by odnieść zwycięstwo, które - jak zauważono - było zaskakujące i nieoczekiwane. Podejście, w którym jedna ze stron nie oczekuje zwycięstwa, jest nieczęstym zjawiskiem, ale równocześnie pokazuje trend polegający na braku elastycznego podejścia i dalekowzrocznego myślenia, a to nigdy nie jest dobrym prognostykiem na przyszłość. NATO przetrwało nie dlatego, że jest silne siłą swojego lidera, jak chcieliby postrzegać Pakt Północnoatlantycki Amerykanie, lecz dlatego, że otworzyło się na nowe możliwości, które dawały państwa wyrosłe na gruzach Imperium Sowieckiego, tak w sensie wewnętrznym (republiki związkowe), jak i zewnętrznym (państwa satelickie).

Proces włączania ich w struktury natowskie stał się przyczynkiem do dalszego rozwoju. Bez tego organizacji groziła stagnacja, a w konsekwencji prawdopodobna likwidacja. Zwłaszcza że takie państwa jak Francja dość sceptycznie odnosiły się do kwestii liderowania organizacji przez Stany Zjednoczone Ameryki. Przyjęcie do sojuszu nowych członków w pewnym stopniu ugruntowało pozycję Waszyngtonu jako miejsca odniesienia dla tych, którzy chcieli zbudować nowy demokratyczny świat ${ }^{17}$.

Problemem w tego rodzaju idealistycznym podejściu jest to, że z czasem można zapomnieć o faktycznych celach zawierania sojuszu, które były odmienne dla Zachodu budującego NATO ze względu na groźbę idącą od strony ZSRR, a państwa

15 R.A. Kosta, Konflikty - Kolonializm - Fundamentalizm w przestrzeni bliskowschodniej, Torun 2013, s. 142-175.

16 A gdy to poczucie tracą, radykalizm i emocje biorą górę nad racjonalizmem. O tym, jak zgubne jest schematyczne podejście, pisze w swoich wspomnieniach z wojen indochińskich major służb specjalnych. Por. J.L. Plaster, SOG. Tajne wojny amerykańskich sił specjalnego przeznaczenia $w$ Wietnamie, przeł. J. Kozłowski, Warszawa 1998, passim.

17 Por. R. Kuźniar, Droga do wolności. Polityka zagraniczna III Rzeczpospolitej, Warszawa 2008, s. 216-253. 
dawnego bloku wschodniego wstąpiły do sojuszu, aby takie groźby nie pojawiły się także wobec nich ze strony Federacji Rosyjskiej lub innego mocarstwa. W tej grupie nie było jednak niepaństwowych, międzynarodowych organizacji terrorystycznych, bo nikt nie przewidział, że pustka po zimnej wojnie może zostać wypełniona innymi niż liberalne poglądami. Demokratyczny system sprawowania władzy nie musi być dla wszystkich narodów świata tym jedynym i wyjątkowym. Zwłaszcza gdy pamięta się o tym, że pomimo innych celów drogi dochodzenia i chronienia własnych interesów mogły czasem być podobne. Jak operacja Trzech Muszkieterów w 1956 r., która ostatecznie położyła kres istnieniu dominacji kolonialnej i utrwaliła dwubiegunowy podział świata, choć intencje uczestników konfliktu w Suezie były zgoła inne. W polityce dość często zachodzi sytuacja, w której zakładane cele zostają zarzucone lub przekształcone $\mathrm{w}$ fazie realizacji ${ }^{18}$.

To nie jest dobrze przyjmowane przez żadne społeczeństwo, zwłaszcza gdy takie państwa jak Królestwo Hiszpanii, Anglia czy Francja nie radzą sobie z terroryzmem, mimo że od dziesięcioleci miały do czynienia $\mathrm{z}$ różnymi jego formami, a ich procedury bezpieczeństwa były bardziej restrykcyjne niż amerykańskie przed 11 września 2001 r. Europa Środkowa i Wschodnia, zostając partnerem, stała się również beneficjentem problemów, które powstały w trakcie dziesięcioleci funkcjonowania NATO. Terroryzm był jednym, ale nie najważniejszym $\mathrm{z}$ nich. Jednak medialne wypowiedzenie wojny Al-Kaidzie sprawiło, że o zjawisku, o którym mówiono sporadycznie, zazwyczaj po zamachu na którąś z baz amerykańskich na Bliskim Wschodzie czy porwaniu dyplomaty, współcześnie praktycznie nie można zapomnieć. Terroryzm stał się tak powszechny jak choroby zakaźne pustoszące kontynent europejski w średniowieczu i mimo rozwoju technologicznego nie znaleziono metod, które położyłyby mu kres. Warto podkreślić, że są metody zwalczania, ale nie zwalczenia. Ta subtelna różnica sprawia, że terroryzm nadal będzie głównym problemem Paktu Północnoatlantyckiego i tym samym może być czynnikiem odwracającym uwagę od innych zagrożeń, które mogą powstać za sprawą ambicji mocarstw, dla których podobnie jak dla terrorystów demokracja jest pustym sloganem w porównaniu z siłą militarną, co widać po rosnącym znaczeniu takich państw jak Korea Północna, która co jakiś czas grozi światu swoim programem broni atomowej ${ }^{19}$.

\section{Podsumowanie}

Z poczynionej analizy wynika, że współczesną scenę międzynarodową zdominował egoizm narodowy. Problemem pojawiającym się w tej części rozważań jest to, jak to wszystko, co zostało zawarte $\mathrm{w}$ analizie, ma się do wyzwań,

18 Por. D. Bensimon, E. Errera, Żydzi i Arabowie. Historia współczesnego Izraela, przeł. R. Gromacka, K. Pruski, Warszawa 2000, s. 164-165.

19 R.A. Kosta, Wektory polityki zagranicznej państw pretendujących do roli mocarstw, Częstochowa 2013, s. 141-170. 
które stoją przed Paktem Północnoatlantyckim. W uproszczeniu można pokusić się o stwierdzenie, że istota skuteczności sojuszu leży w jego wojskowym, a nie politycznym aspekcie. Jeżeli członkowie NATO zamiast kierować się partykularnym i krótkowzrocznym interesem, jak miało to miejsce w przypadku Iraku, będą uwzględniać prawdopodobne konsekwencje swoich działań, to łatwiej wypracują wspólną strategię odpowiadania na potencjalne zagrożenia.

Ważnym elementem wymiaru wojskowego sojuszu jest skumulowanie wysiłku, aby uniknąć sytuacji, w której doszłoby do mitologizowania zagrożeń. Chodzi tu o to, aby nie nadawać specjalnej rangi takim zjawiskom jak terroryzm, bo - jak wynika z prowadzonych badań - sprzyja to wzrostowi ich znaczenia, a w konsekwencji ich oddziaływanie wzrasta zamiast maleć.

NATO powstało w specyficznym okresie ideologicznej wojny, która zakończyła się wraz z upadkiem Bloku Wschodniego i rozpadem ZSRR. Moment, w którym dwie dotychczas wrogie strony zawierają sojusz, musi zmienić jakościowy układ sił na świecie, co rzeczywiście miało miejsce. Problemy, które później wynikły, nie były następstwem różnic ideologicznych, lecz pustki, która pojawia się po każdym konflikcie. Ta pustka podobnie jak czarna dziura z perspektywy wszechświata wciąga wszystko, co jest w jej zasięgu. W omawianym wypadku były to rzesze dawnych mudżahedinów, najemników i specjalistów od szeroko rozumianego sabotażu i dywersji. Nie byli oni ideologicznymi fanatykami, ale pozostając przez długi czas bez zatrudnienia i czując się zdradzonymi przez dawnych mocodawców, stali się podatni na przekaz kogoś, kto dawał im możliwość realizacji w jedynej dziedzinie, na której się znali. Tak narodziła się XXI-wieczna wersja terroryzmu międzynarodowego i to ona jest głównym przeciwnikiem NATO, ponieważ wydaje się niezrozumiała. Jednak po analizie uwzględniającej zarówno poglądy Arona, jak i brzytwę Ockhama można zauważyć, że to niezrozumienie dotyczy politycznego podejścia do tej kwestii, bo z wojskowego punktu widzenia żadne plany masowych interwencji nie zdadzą egzaminu. Terroryzm nie jest bowiem kwestią polityków, lecz wyspecjalizowanych jednostek wojskowych, takich jak: GROM, SAS, GREEN BERETS itp., grup, które są efektywne w sytuacji zwalczania ekstremistów ${ }^{20}$. Jak udowodniły wojny indochińskie, ich brak skutkował klęską Zachodu i cierpieniem dotkniętych konfliktem społeczności, zagrażającym ich fizycznej egzystencji ${ }^{21}$.

Plany polityczno-wojskowych mariaży powinny być domeną takich organizacji jak ONZ czy Unia Europejska. NATO nie powinno i nie może powielać ich zadań, gdyż to mija się z celem jego istnienia. NATO z 1949 r. i z 1999 r. oraz z 2019 r. to różne formaty współpracy, które łączy historyczna nazwa. Zbytnie jej upolitycznienie nie sprzyja konsolidacji w celu realizacji konkretnych zadań. Jeżeli bowiem Pakt Północnoatlantycki ma zapewnić bezpieczeństwo nie tylko swoich członków, lecz ma również czuwać nad tym, by nikt nie naruszył światowego ładu i nie dążył

20 Szerzej na temat jednostek specjalnych pisze G. Stewart, SAS. Elita wojsk Brytyjskich, przeł. J. i S. Kodym, Warszawa 1999, s. 59-144.

21 J.L. Plaster, op. cit., passim. 
do destabilizacji, to nad jego działaniami muszą czuwać ci, którzy mają koncepcję, jak te zadania przeprowadzić, by plany NATO skutkowały konkretnymi reakcjami zmniejszającymi zagrożenia. Na koniec nie można zapominać o kwestiach finansowych. Wszyscy członkowie są zobowiązani do płacenia składek i podnoszenia wartości bojowej swoich armii. Często jednak zapomina się o tym, że nierealne strategie wykorzystania tych sił czynią z nich wyłącznie straszak, a nie realne zagrożenie dla potencjalnego przeciwnika. Ponadto w świecie, w którym każda informacja ma swoją konkretną wartość, walka z zagrożeniami toczy się na innym niż militarny froncie, albowiem tzw. pierwszą linię tworzą agendy wywiadowcze i wspomniane już siły specjalne i to od ich skuteczności zależy współczesne bezpieczeństwo. Właśnie dlatego ich rozwój powinien być priorytetem całości sojuszu, a nie polityczne rozgrywki między politykami, jak ma to miejsce w przypadku stricte polityczno-gospodarczych organizacji. Jeżeli ten warunek będzie spełniony, to NATO przestanie być postrzegane jako kolejny ekskluzywny klub i stanie się realnym narzędziem nadzorującym, by bezpieczeństwo międzynarodowe nie stało się li tylko medialnym sloganem, który nie zawiera żadnych konkretnych treści. Dlatego też powinno być to uwzględnione w strategiach polityki obronnej takich państw jak Polska, aby pokazać, że nie są one tylko tzw. kwiatkiem do kożucha USA, ale stanowią o sobie, prezentując niezależną politykę opartą na porozumieniu, a nie konflikcie, co jest warte podkreślenia, a dla decydentów politycznych - zapamiętania.

\section{Bibliografia}

Amin S., Zmurszały kapitalizm, przeł. R. Wojna, Z.M. Kowalewski, Warszawa 2004.

Andrew Ch., Gordijewski O., KGB, Warszawa 1999.

Aron R., Wojna i pokój między narodami (teoria), przeł. A. Mielczarek, Warszawa 1995.

Bensimon D., Errera E., Żydzi i Arabowie. Historia współczesnego Izraela, przeł. R. Gromacka, K. Pruski, Warszawa 2000.

Dobry M., Socjologia kryzysów politycznych, Warszawa 1995.

Jaber H., Hezbollah. Walka i zemsta, przeł. J. Kozłowski, Warszawa 1999.

Kosta R.A., Idea bezpieczeństwa i pokoju w polityce mocarstw anglosaskich, Częstochowa 2016.

Kosta R.A., Konflikty - Kolonializm - Fundamentalizm w przestrzeni bliskowschodniej, Toruń 2013.

Kosta R.A., Oblicza zjawiska polityki w życiu publicznym w XXI wieku, Częstochowa 2016.

Kosta R.A., Wektory polityki zagranicznej państw pretendujących do roli mocarstw, Częstochowa 2013.

Kuźniar R., Droga do wolności. Polityka zagraniczna III Rzeczpospolitej, Warszawa 2008.

McCauley M., Rosja, Ameryka i Zimna Wojna, przeł. R.A. Galas, Wrocław 2001.

Organizacje w stosunkach międzynarodowych. Istota - Mechanizmy Działania — Zasięg, red. T. Łoś-Nowak, Wrocław 2009.

Plaster J.L., SOG. Tajne wojny amerykańskich sit specjalnego przeznaczenia w Wietnamie, przeł. J. Kozłowski, Warszawa 1998.

Stewart G., SAS. Elita wojsk brytyjskich, przeł. J. i S. Kodym, Warszawa 1999. 
Rola NATO w regulacji światowego porządku. Wyzwania i zagrożenia

Tanner S., Wojny Bushów. Ojciec i syn jako zwierzchnicy sił zbrojnych, przeł. J. Lang, Wrocław 2007.

Todd E., Schyłek imperium. Rozważania o rozkładzie systemu amerykańskiego, przeł. A. Szeptycki, K. Mączyńska, Warszawa 2003.

Zięba R., Wspólna polityka zagraniczna i bezpieczeństwa Unii Europejskiej, Wrocław 2007. 